\title{
REGIONAL PUBLIC SERVICE MEDIA ORGANIZATION IN POLAND IN THE ERA OF MEDIA CONVERGENCE
}

\author{
ADAM RUDAWSKI \\ University of Szczecin, Faculty of Management and Economics of Services, POLAND \\ e-mail: adam@rudawski.pl
}

\begin{abstract}
RECEIVED
ACCEPTED

10 December 2018

28 December 2018

JEL

CLASSIFICATION

$\mathrm{M} 12, \mathrm{M} 54, \mathrm{O} 33, \mathrm{P} 41$

KEYWORDS

media, media management, public service media in Poland, media convergence

ABSTRACT

This paper presents the concept of a new regional public service media organization in Poland. Changes in social communication and in particular Internet and digital media dissemination resulted in progressing media convergence. It brings the necessity of change not only of devices for producing and receiving media content (information, music, movies), but also organizational changes in companies providing media services themselves. This is about the unification and universalism of communication, i.e. suitability to content 'utilization' in many formats (text, audio, photo, video), but also economic saving in content acquiring and monetization (getting revenues from media activity). New technologies entail changes in work organization and thus modifications in organizational structure. The paper presents the model organizational structure of new regional, public service media entities that considers media convergence and necessary modifications in journalistic work resulting from changes that occur.
\end{abstract}

\section{Introduction}

The current model of public service media operating in Poland was established by the Broadcasting Act as of 29 December 1992. Public radio and television broadcasting entities operate exclusively in a form of the soleproprietor joint stock company of the State Treasure, hereinafter referred to as "the company". Public television is formed by the company "Telewizja Polska - Spółka Akcyjna", established for the purpose of producing and 
transmitting national programme services I, II and TV Polonia as well as regional television programme services. Regional branches of the company "Telewizja Polska - Spółka Akcyjna" have their head offices located in: Białystok, Bydgoszcz, Gorzów Wielkopolski, Gdańsk, Katowice, Kielce, Kraków, Lublin, Łódz, Opole, Olsztyn, Poznań, Rzeszów, Szczecin, Warszawa, Wrocław. Public radio comprises of: 1) "Polskie Radio - Spółka Akcyjna" established to produce and transmit nationwide radio programme services and programme services for listeners abroad; 2) companies established to produce and transmit regional radio programme services, hereinafter referred to as „the regional radio companies” (Art. 26 of Ustawy...,1992).

The progressing process of media convergence and growing importance of Internet and social media in social communication require a new model of operation of public service media, tailored to new market challenges of a model of public media operation in Poland. The current concept of public media operation was created at the beginning of 1990s, before Internet and social media become commonly available in Poland. It resulted from the traditional media division into radio and television programme services. Today, a traditional operation of radio and television programme services does not translate into effectiveness of media activity. Effective production of interesting content and its broadcasting in all distribution channels - traditional, i.e. radio (FM) and television (DVBT) and on Internet is more important. Thus it is essential that a new concept would assume regional media organization to achieve optimal management of produced content and to provide service to all recipients (listeners, viewers and Internet users). The goal of this article is to develop an original concept on how to organize the regional public media in Poland in the context of progressing media convergence. Following this new concept, a new type of media organization was developed. The center of interest of its operational activity concentrates on acquiring and dissemination of critical news and entertainment programmes and on combining in one entity (company) several media activities: Internet portal, social media and radio and television programme services.

\section{Media convergence}

Technological penetration in media, mainly due to global and commonly available Internet network results in the need of the new approach to work organization of media services providers. Not only universality of broadcast content, covering in the same time printed and audiovisual transmission is important, but also a requirement to implement modifications in the journalist's work. As A. Koroczyński noted (2012, p. 33) "media convergence entails deep technology transformation in the journalist's work, a profession of journalist itself. It even creates symbiotic forms of cooperation between various media services, new relations between media organizations and professional communicators". Therefore, not only new forms of organization of media work are needed, but it is also necessary to revise journalists' training programs so as they are able to use new opportunities of the aggregated social communication. "New technologies and wider range of distribution channels, through which recipients are reached, put high demands on graduates from journalistic majors" (Szynol, 2011, p. 49). At the same time, you must not forget that the final recipient (reader, listener, viewer, Internet user) is the subject of all processes involving content gathering and transmission. In this context, one must agree with Radek's statement (2012, p. 135) that "diffusion of transmission methods of various information, e.g. relying on wide use of Internet makes the process much easier and pleasant. The global network is a very convenient tool that allows reading the press, listen to the radio or watch television." 
Media experts discuss also multitasking or multiskilling (having many skills by employees of media companies), a phenomena resulting from technological development of mass media. These concepts are related to the need of combining many skills and executing various tasks so far executed by individual experts, by one employee (Szynol, 2012-2013). The above phenomena make it necessary to correct (adjust) new challenges in terms of technology and organization in the existing public media system.

\section{Assumptions of a new model of regional public media organization in Poland}

The concept assumes liquidation of 17 regional radio programme service providers and 16 regional branches of Telewizja Polska, which has to be preceded by the amendment of the Broadcasting Act. They would be replaced by 16 limited liability companies under the name of Media Regionalne and the city where their head offices would be located. New companies would take-over necessary movables and immovable property from closed entities. They would not be obliged to take-over all the assets and former employees of organizations subject to liquidation. The remaining, but not taken over assets from the closed entities would be subject to sale according to liquidation procedure carried out in accordance with the provisions of the Code of Commercial Partnership and Companies. The employees dismissed would be entitled to all and any rights provided for in the Labor Code in such a case. The presidents of management boards of new companies - Media Regionalne, consisting of one person - would be appointed for a four-year term of office in open and public competitions organized by the National Broadcasting Council or another entity appointed by the legislator. The above operations would result in establishing the following entities:

- Media Regionalne Białystok Sp. z 0.o. (short name: MR Białystok),

- Media Regionalne Bydgoszcz Sp. z 0.0. (short name: MR Bydgoszcz),

- Media Regionalne Gdańsk Sp. z 0.o. (short name: MR Gdańsk),

- Media Regionalne Katowice Sp. z 0.o. (short name: MR Katowice),

- Media Regionalne Kraków Sp. z 0.o. (short name MR Kraków),

- Media Regionalne Kielce Sp. z 0.o. (short name: MR Kielce),

- Media Regionalne Lublin Sp. z 0.o. (short name: MR Lublin),

- Media Regionalne Łódź Sp. z 0.0. (short name: MR Łódź),

- Media Regionalne Olsztyn Sp. z 0.o. (short name: MR Olsztyn),

- Media Regionalne Opole Sp. z o.o. (short name: MR Opole),

- Media Regionalne Poznań Sp. z 0.o. (short name: MR Poznań),

- Media Regionalne Rzeszów Sp. z 0.0. (short name: MR Rzeszów),

- Media Regionalne Szczecin Sp. z 0.0. (short name: MR Szczecin),

- Media Regionalne Warszawa Sp. z 0.o. (short name: MR Warszawa),

- Media Regionalne Wrocław Sp. z o.o. (short name: MR Wrocław),

- Media Regionalne Zielona Góra Sp. z 0.o. (short name: MR Zielona Góra).

A legal form of the limited liability company has been adopted in this concept, which is more appropriate for smaller than national organizations, like TVP SA and Polskie Radio SA. In addition, this form does not require establishing supervisory boards and exercising by the National Broadcasting Council or another entity appointed by the legislator control over a company or performing a function of the general assembly. Necessity to negotiate 
the provisions of the new act with the European Union must also be considered, because these are new entities established after the Polish accession, thus any public financial support requires EU notification.

The newly established entities would be the publisher of the regional Internet portal and the broadcaster of the radio and television programme. New companies would take over some brands of former broadcasters and branches of TVP. For example "MR Białystok" would be the publisher of the regional Internet portal and the broadcaster of Radio Białystok and Telewizja Białystok (not TVP Białystok, not to duplicate the name of national broadcaster).

\section{Oryanisation and management of Media Regionalne}

According to the proposed concept, companies would operate independently of one another and would be independent from the supervising entity, with regard to programme content. They would take own managerial decisions with regard to: organization, investments, programme or personnel - depending on demands from citizens of a region and company, as an economic operator. For proper cost parametrization and organizational transparency, all Media Regionalne would operate in the identical organizational structure (Figure 1). It would be defined in the statute of the company and all Media Regionalne would have the same organizational chart, described in by-laws (approved by National Broadcasting Council or another entity appointed by the legislator).

Organizational chart presented in Figure 1 is modelled on M. Porter (1985) value chain, widely disseminated in the literature, dividing the company's activities into primary ones (programme-related - production and content broadcasting) and support ones (bookkeeping, HR, transport, guards etc.), as well as its modified version, so called value chain 2.0, proposed by Comtess and Huang (2008) and described by Mazurek (2012, pp. 56-58). Management of project teams has been applied there. It is based on BBC experience, where Internet and social media is the core of journalistic activity (Ah, 2013).

The company would be managed by the Management Board consisting of one person. The President of the Management Board would be a supervisor of all employees and would manage the the whole entity. All directors of basic (programme-related) activity: Editor-in-chief, Radio Programme Director, Television Programme Director and auxiliary (administrative) activity: Technical Director, Chief Accountant, Personnel Manager, Marketing Manager would report to him. The President of the Management Board would supervise the office of the Management Board (1 person - an assistant of the President of the Management Board) and would cooperate with a Legal Advisor based on a contract for provision of legal services concluded with an external legal office (outsourcing). 


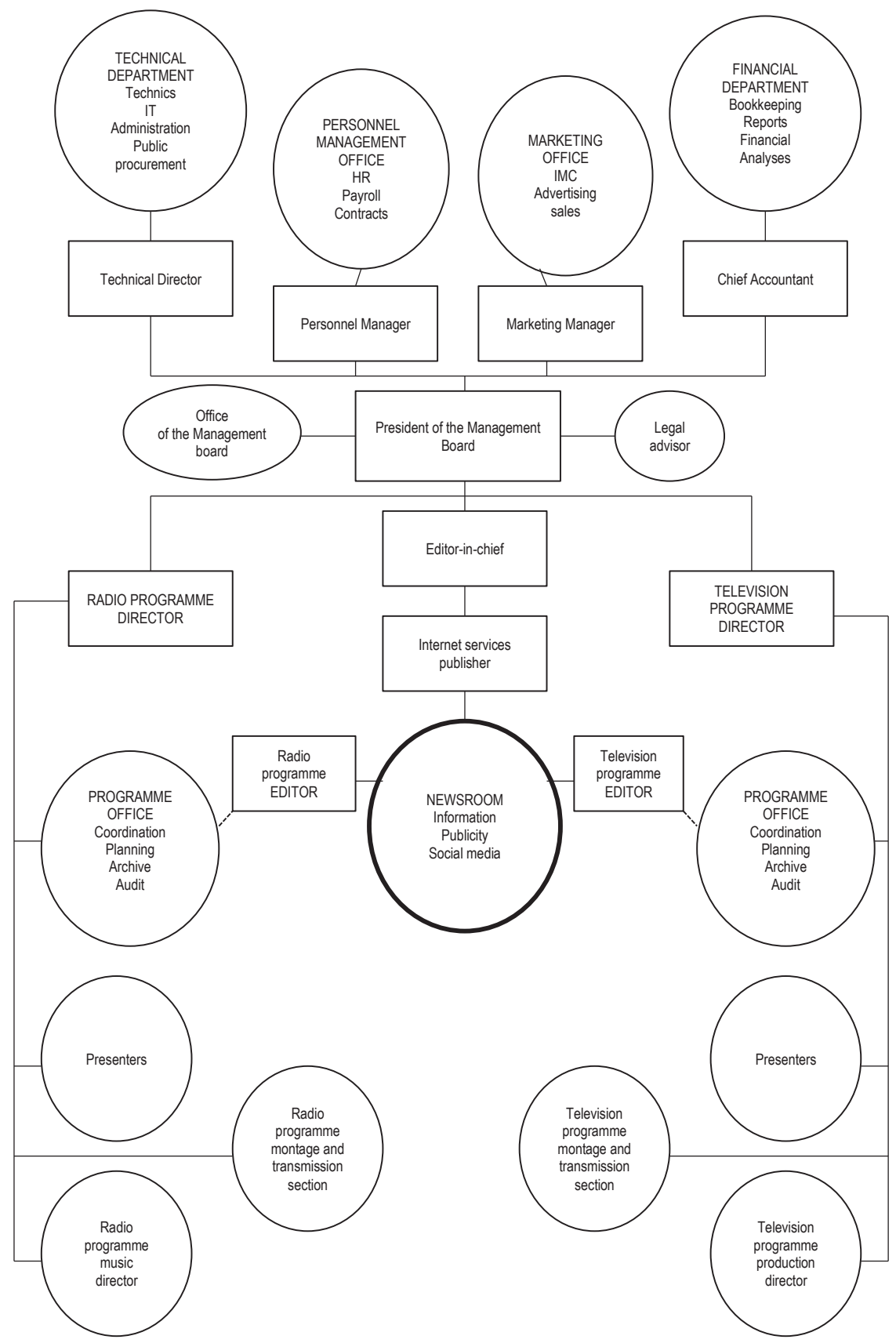

Figure 1. Media Regionalne organizational chart

Source: own elaboration. 


\section{Primary activity (programme-pelated)}

Newsroom would be the core of the program activity. It would perform works for all company's information activities. Its employees would be responsible for the preparation of content, audio and video materials for all information services - the portal, social media and radio and television programmes. All reporters and publicists as well as all editors of information services of individual media (Internet portal, radio, television) would work there. The position of the website publisher would be subordinated to the Editor-in-chief. It would be rotational depending on the date of the website release and the availability of individual publishers. The concept assumes that the newsroom would also employ publicists who would participate in the work of the newsroom and prepare publications. The Editor-in-chief would be responsible for all information and the company's entire journalism. With regard to other programmes he would cooperate with Radio and Television Programme Directors. The Editor-inChief would also be the head of the newsroom and the publisher of the portal, one of editors would replace him, if required. Programme offices would coordinate the work of radio and television programme services for other programmes. According to the assumptions, every day the work of editorial office would start with a meeting in the newsroom, where there would be reporters, publicists, editors, Editor-in-Chief and a person from the Marketing Office responsible for the current promotion. Employment in the newsroom should not exceed 30 people. Some people should be employed in full-time, some as co-workers, depending on the company's needs and involvement in a programme. Journalists in the newsroom would be employed at the posts of: reporter, editor, publicist, and commentator. They would receive basic salary (slightly higher above the minimum salary level) and compensation (depending on the nature of performed tasks - some employees would be paid for making specific materials, some in a form of flat rate payment).

In addition to information services and journalistic programmes, the Radio Programme Director would be responsible for the entire radio programme, and the Television Programme Director for entire television program. They would supervise work of programme offices, which would arrange broadcasting lists and coordinate the entire programme. Programme offices would also make necessary purchases of programmes outside the company. They would be responsible for the execution of the declared number of mission programmess and compliance with the statutory restrictions on radio and television programmes - respectively. They would also care about archiving a programme and managing company's archival materials. Approximately 3 persons would be employed in each office. In addition to the programme offices, the Radio Programme Director would supervise the Presenters (about 10 people), the Radio Programme Music Director (1 person) and the Radio programme montage and transmission section (about 6 people). The Television Programme Director would also supervise the Presenters (about 5 people), the Television Programme Production Director (1 person) and the Television Programme montage and transmission section (about 12 people). Presenters, programme offices, and montage and transmission sections would not have managers; their role would be fulfilled by Programme Directors.

\section{Support activity (administrative and technological)}

The proposed concept assumes that with regard to the auxiliary activity the President of the Management Board will supervise the Technical Director, responsible for technical and technological functioning, as well as for the maintenance and purchase of all equipment for the company. His responsibilities will also include supervising the IT department and ensuring production, transmission and broadcasting of radio and television programmes as 
well as providing access to the regional portal on Internet. The Technical Director will also be a superior to transport and real estate administration. His job will also include ensuring the protection and cleanliness of buildings, based on outsourcing. He will be the chairman of the contract award committee; he would be also responsible for administration of the company's investments. Approximately 10 people would be employed in the technical department. The Financial Department would be managed by the Chief Accountant. In this section, two more people would be employed ( 3 in total) - one involved in bookkeeping and the other preparing economic plans and financial reports. The Personnel Management Office would also report to the President of the Management Board. Two people would work in the office, i.e. the Personnel Manager and the Payroll specialist. Marketing Manager would be responsible for the Integrated Marketing Communication (IMC) and the sale of advertisements on the portal, on the radio and on television. He would report directly to the President of the Management Board. $\mathrm{He}$ would also be responsible for the technical implementation of current promotional campaigns of individual antennas and the portal, agreed as part of the promotion project team. In addition to the Marketing Manager, the team would consist of the Radio Programme Director, the Television Program Director and the employee of the creative promotion office. Two people would work in promotional activities in the marketing office, and about four people would be involved in sale of advertisements.

\section{Nature of Media Regionalne programmes}

Content on the portal, in the radio and television programmes should correspond to the expectations of the region's listeners and viewers. It should primarily provide local news, because this area has shortfalls, not filled by commercial stations. One should not forget about entertainment and the accompanying nature of regional media services. These companies should be leaders in the attractiveness of the programme and its professionalism as well as in audience rating and opinion-forming. The portal should not charge for the content presented. The radio programme should be broadcast 24 hours, with hourly information service between 6:00 and 23:00. Radio-played music should follow AC (Adult Contemporary) ${ }^{1}$ format. The television programme should be created with focus on local news and journalism, broadcast for a minimum of 6 hours plus repetition. First, materials for radio and television programmes should be sent to the regional portal.

\section{Proposal of algorithm on radio and television subscription distrihution}

Radio and television subscription or other fee for media services should have an explicit and transparent algorithm. Presented concept assumes the fee to comprise of five parts:

1. Coverage of depreciation costs.

2. Coverage of portal server fees, broadcast and radio and TV signal charges.

3. A fixed amount for all companies to cover the annual maintenance of the portal.

4. A fixed amount for all companies to cover production of one hour of radio programme.

5. A fixed amount for all companies to cover production of one hour of tv programme.

${ }^{1} \mathrm{AC}$ - played-music format of the radio station, whose target group is mainly men and women aged 30-54. It consists of tracks from the 80 's to contemporary hits, especially pop music. 


\section{Conclusions}

Deep and rapid changes in the media services environment determine the need for change in their internal organization. Media convergence, a much faster process of obtaining and publishing journalistic materials, enforces the adjustment of the organizational structure of media services providers, including public ones, to new market requirements. The change of the organizational structure must occur not only in the sphere of acceleration of program broadcasting processes (content), but also take into account that currently it should be managed in various types of media services activity (video, audio, text) at the same time. Hence the idea presented in the study of combining traditional media services (regional radio and television) and adding the Internet portal into one entity, would provide the basis for organizing a modern entity that fully exploits the capabilities of all distribution channels.

\section{References}

Ah (2013). BBC News' television output to moves to new studios at Broadcasting House. Retrieved from: https://www.bbc.co.uk/ mediacentre/latestnews/2013/tv_news_move.htlm.

Art. 26 ustawy z dnia 29 grudnia 1992 roku o radiofonii i telewizji. Dz. Urz. 1993, no. 7, item. 34.

Comtess, X., Huang, J. (2008). Value chain 2.0, Think Studio. Retrieved from: www.thinkstudio.com/text/chain20.pdf.

Koroczyński, A. (2012). Dziennikarstwo międzynarodowe w warunkach konwergencji środków masowego przekazu. In: Z. Oniszczuk, M. Wielopolska-Szymura (eds.), Konwergencja mediów masowych i jej skutki dla współczesnego dziennikarstwa, t. 1. Katowice: Wydawnictwo Uniwersytetu Śląskiego.

Mazurek, G. (2012). Znaczenie wirtualizacji marketingu w sieciowym kreowaniu wartości. Warszawa: Poltext.

Porter, M. (1985). Competitive advantage. New York: The Free Press.

Radek, R. (2012). Postęp konwergencji mediów na przykładzie stron internetowych wybranych euroregionów. In: M. Gierula, P. Szostok (eds.), Konwergencja mediów masowych i jej skutki dla współczesnego dziennikarstwa, t. 2. Katowice: Wydawnictwo Uniwersytetu Śląskiego.

Szynol, A. (2011). Dziennikarstwo specjalistyczne czy multimedialne - kilka uwag na temat współczesnego kształcenia dziennikarzy. In: S. Gawroński (ed.), Dydaktyka dziennikarstwa. Opinie i postulaty. Kraków-Rzeszów-Zamość: Konsorcjum Akademickie.

Szynol, A. (2012-2013). Konwergencja mediów w praktyce. Media - Kultura - Społeczeństwo, 7-8, 5-20.

Cite this article aS: Rudawski, A. (2018). Regional public service media organization in Poland in the era of media convergence. European Journal of Service Management, 4 (28/2), 379-386. DOI: 10.18276/ejsm.2018.28/2-45. 